\title{
Three-dimensional morphometric analysis of mandibule in coronal plane after bimaxillary rotational surgery
}

Sung-Tak Lee, Na-Rae Choi, Jae-Min Song and Sang-Hun Shin ${ }^{*}$

\begin{abstract}
Background: The aim of this report is to present a new reference for aesthetic mandible surgery using three-dimensional cone-beam computed tomography-based treatment planning for orthognathic surgery which can be implemented in surgical planning and perioperative procedure.
\end{abstract}

Methods: To make an objective standard for evaluating aesthetic mandibular outline, we make an aesthetic scoring criteria with consideration of asymmetry, broad mandibular border line, and prominent mandibular angle. Two maxillofacial surgeons and two orthodontists rated their aesthetical evaluation from 1 to 5 . Experimental group consisting of 47 female and 38 male patients who had rotational orthognathic two-jaw surgery from 2010 to 2011 were chosen according to aesthetic scoring done by two maxillofacial surgeons and two orthodontists. A high aesthetic score $(\geq 16)$ means the facial contour is symmetric, with no broad and narrow aesthetic mandible frontal profiles. Control A group consisted of ten female and ten male patients who had no orthognathic surgery experience and low aesthetic score $(\leq 10)$. Control B group consisted of ten female and ten male patients who had no orthognathic surgery experience and had anaesthetic mandibular frontal profile and a high aesthetic score $(\geq 16)$. The three-dimensional image of the patient was taken from dental cone-beam CT (DCT) scanning (experimental group and control A group: 6 months DCT after surgery, control B group: 1st visit DCT). Each DCT was reformatted to reorient the 3D image using 3D analyzing program (OnDemand3D, cybermed Inc, CA, USA). After selection of 12 landmarks and the construction of reoriented horizontal, vertical, and coronal reference lines, 15 measurements were taken in 3D analysis of frontal mandibular morphology. Afterwards, horizontal and vertical linear measurements and angular measurements, linear ratio were obtained.

Results: Mean $\mathrm{GO}_{\mathrm{Rt}}^{\prime} \mathrm{Me}^{\prime}-\mathrm{GO}_{\mathrm{Lt}}^{\prime}$ angular measurement was $100.74 \pm 2.14$ in female patients and $105.37 \pm 3.62$ in male patients. These showed significant difference with control A group in both genders. Ratio of $\mathrm{GO}_{\mathrm{Rt}}{ }_{\mathrm{t}} \mathrm{GO}_{\mathrm{Lt}} \mathrm{Lt}^{-} \mathrm{Me} \mathrm{e}^{\prime}$ length to some linear measurements (ratio of $\mathrm{Me}^{\prime}-\mathrm{Cd}_{\mathrm{Rt}}^{\prime} \mathrm{Cd}_{\mathrm{Lt}}^{\prime}$ to $\mathrm{Me}^{\prime}-\mathrm{GO}_{\mathrm{Rt}} \mathrm{Go}_{\mathrm{Lt}}^{\prime}$, ratio of $\mathrm{Me}^{\prime}-\mathrm{Go}^{\prime}$ to $\mathrm{Me}^{\prime}-\mathrm{Go}_{\mathrm{Rt}}{ }_{\mathrm{Go}}{ }_{\mathrm{Lt}}$, ratio of $\mathrm{Go}_{\mathrm{Rt}}-\mathrm{GO}_{\mathrm{Lt}}$ to $\left.\mathrm{Me}^{\prime}-\mathrm{Go}_{\mathrm{Rt}}^{\prime} \mathrm{GO}_{\mathrm{Lt}}^{\prime}\right)$ showed significant difference with control A group in both genders.

Conclusion: This study was intended to find some standard measurement of mandible frontal view in 3D analysis of aesthetic patient. So, these potential measurement value may be helpful for orthognathic treatment planning to have more aesthetic and perspective outcomes.

Keywords: V-line, Frontal reference, Aesthetic mandibular outline, Orthognathic surgery, Rotational surgery

\footnotetext{
*Correspondence: ssh8080@pusan.ac.kr

Department of Oral and Maxillofacial Surgery, School of Dentistry, Pusan

National University, 49 Busandaehak-ro, Mulgeum-eup, Yangsan 626-870, Korea
} 


\section{Background}

The frequency of the bimaxillary orthognathic surgery has increased due to the aesthetic and functional outcomes involving rotational movement of the maxillamandibular complex. It leads to the reduction of the perpendicular length of the face [1], and the increased amount of posterior movement of the distal segment, reduction of posterior vertical height of the maxilla, and forward movement of the perialar area $[2,3]$. As a result, the mandibular outline in frontal view has an aesthetic line, called as $V$-line, consistent with the preference of the modern people advancing the smooth and slender facial form.

On the other hand, even with the development of a diagnostic modality for facial skeleton, most of the planning for orthognathic surgery is still established by lateral profile analysis depending on two-dimensional lateral cephalometry $[4,5]$. As a result, the exact anteroposterior movement of maxillomandibular complex is possible. On the contrary, there are no measurement points and values as a diagnostic tool to analyze frontal profile, especially the mandibular outline that affects substantially on aesthetic frontal looks. Hence, the mandibular outline in frontal view after surgery tends to be decided by the subjective preference of the operator. It is one of the causes of additional surgery to correct unsatisfactory facial contour after adaptation of the soft tissue.

There were some previous studies to investigate the reference point and referential measurement in frontal view with skull PA X-ray film. However, they had no perspective and utility because of the difficulty of positioning the reoriented natural head position and selecting the specific anatomical points to overlay a twodimensional plain skull PA film.

Meanwhile, using conventional two-dimensional frontal cephalometric analysis was difficult to find the significant measurement point by overlapping bony structure due to instability that came from the motion of the patient $[6,7]$. It became possible to overcome the problem of the conventional 2D frontal cephalometry to analyze frontal profile due to the development of a variety of threedimensional(3D) representing analysis modality, such as 3D computed tomography, 3D magnetic resonance imaging, 3D ultrasonography, laser scanning, and digital sterophotogrammetry [8].

Nevertheless, there are no studies using threedimensional modality to find a useful reference point and measurement yet. So, we want to investigate a useful reference point and measurement in frontal view in order to help to make a surgical plan for more aesthetic results and perspective outcomes.

The purpose of this study is to evaluate the usefulness of $3 \mathrm{D}$ computerized tomographic analysis as a diagnostic tool of orthognathic surgical planning for getting aesthetic mandibular line in frontal view, and to determine the useful reference points and measurements to diagnose the frontal facial plane and make surgical plan for an enhanced functional and aesthetic surgical.

\section{Methods \\ Subject \\ Evaluation for aesthetic mandibular border line in frontal \\ view}

To make an objective standard for evaluating aesthetic mandibular outline, we make an aesthetic scoring criteria with consideration of asymmetry, broad mandibular border line, and prominent mandibular angle (Table 1). Two maxillofacial surgeons and two orthodontists rated their aesthetical evaluation from 1 to 5 resulting in a total score from 5 to 20. A higher aesthetic score was considered as having a more aesthetic mandibular border line in frontal view.

The difference of aesthetical preference between the evaluators may affect the results of study, so we evaluated the inter-rater agreement with the Kappa coefficient. The Kappa coefficient to measure inter-rater agreement for aesthetic mandibular line was more than 0.75 .

\section{Experimental group and control $A$ group}

Clinical and surgical records along with a 6-month postoperative photograph after orthognathic surgery of patients diagnosed with the mandibular prognathism and operated in Department of Oral and Maxillofacial Surgery at Pusan National University Hospital from January 2010 to February 2011 were reviewed retrospectively. Two oral and maxillofacial surgeons and two orthodontists determined the experimental group as the patients with aesthetic mandibular lines with a total score of 16 points or greater by the aesthetic scoring criteria. Patients who had revisional surgery were excluded. Finally, 38 male patients and 47 female patients with a mean age of 22.7 years (range: 20-24 years) were selected as the experimental group. Because they had a high aesthetic score, so, we thought they had aesthetic mandibular outline and such a mandibular outline would be widely accepted as a beautiful face.

And, ten male patients and ten female patients with less than ten points were selected as control group A.

\section{Table 1 Aesthetic scoring criteria}

\begin{tabular}{ll}
\hline Score & Criteria for mandibular inferior border line \\
\hline 5 & No asymmetry, broad, prominent angle \\
4 & No asymmetry, broad, but prominent angle \\
3 & No broad but, asymmetry, prominent angle \\
2 & No asymmetry but, broad, prominent angle \\
1 & Asymmetry, broad, prominent angle \\
\hline
\end{tabular}


Control group A have no aesthetic mandibular outline widely accepted in uncorrected population.

\section{Control group B}

Clinical records and photographs of patients who visited the Department of Orthodontics at Pusan National University Hospital, from January 2010 to February 2011 were reviewed retrospectively. Control group B was selected with inclusion criteria (Table 2) and had 16 points or greater with the aesthetic scoring criteria. Control group B have aesthetic mandibular outlines widely accepted in uncorrected population (Table 3).

\section{Method of study}

\section{Three-dimesional computerized tomography}

By using the dental cone-beam CT (Pax-Zenith 3D, VATECH, Yong-In, Korea, DCT) installed in Pusan University's Dental Clinic Oral and Maxillofacial Radiology Department, the 3D image of the patient was taken (experimental group and control A group: 6 months DCT after surgery, control B group: 1st visit DCT).

\section{Reorientation of 3D computerized tomography image}

The DCT image of all patients was converted to the digital imaging and communication in medicine (DICOM) 3.0 File. DICOM file was reoriented with 3D image by using the OnDemand3D $\mathrm{D}^{\mathrm{Ts}}$ (3D analysis software program, Cybermed Inc., CA, USA). Then, multiplanar reformatted image was accomplished. The reference planes are horizontal reference plane, sagittal reference plane, and coronal plane that is perpendicular to two other reference planes (Table 4, Fig. 1). The reference points were measured on reoriented 3D MPR image (Fig. 2).

\section{The measurement of the reorientated $3 D$ computerized tomography image}

To investigate linear and angular measurement, we needed to establish a second reference point on coronal plane. Second reference point is the meeting point of the coronal plane and the line perpendicular to the line connecting anatomical reference point to coronal plane. All measurements are investigated with second point on coronal plane (measurement plane (Fig. 3). This measuring concept was technically easy and convenient.

We investigated linear and angular measurement consisting of the second point to meet the coronal plane

Table 2 Inclusion criteria of control B group

Class I canine and molar key
No history of orthognathic and orthodontic treatment
Normal dentition including crowding, spacing, supernumerary tooth,
and ectopic eruption
No facial asymmetry

Table 3 Patients distribution

\begin{tabular}{llll}
\hline Group & Female/male & Mean age & Total aethetic score \\
\hline Experimental $(n=85)$ & $47 / 38$ & $22.3 \pm 4.3$ & $\geqq 16$ \\
Control A $(n=20)$ & $10 / 10$ & $23.3 \pm 3.5$ & $<10$ \\
Control B $(n=20)$ & $10 / 10$ & $25.2 \pm 4.5$ & $\geqq 16$ \\
\hline
\end{tabular}

and the vertical line from each reference point to the coronal plane (Table 5, Fig. 4).

\section{Statistical analysis}

By using SPSS for Window version 12.0 (SPSS, Chicago, Il, USA), Independent $t$ test was performed in order to compare the difference between men and women within the experimental, and the difference between experimental group and control group in each group. A $p$ value less than 0.05 was considered to be statistically significant.

\section{Results}

The average and standard deviation of each measurement of men and women in experimental group was calculated, and the comparison of significance between man and woman was evaluated (Table 3). Most of linear and angular measurement did not reveal a significant difference between men and women in experimental

Table 4 Reference point and plane [21, 22] (Figs. 1, 2)

\begin{tabular}{|c|c|}
\hline Landmark & Description \\
\hline Porion $_{R t}\left(P_{R t}\right)$ & The most superior point of the Rt. EAM \\
\hline Porion $_{L t}\left(P_{L t}\right)$ & The most superior point of the Rt. EAM \\
\hline Oribitale (Or) & The midpoint of the infraorbital margin \\
\hline Oribitale (Or) & The midpoint of the infraorbital margin \\
\hline PNS & Tip of the posterior nasal spine \\
\hline Gonion $_{\text {Rt }}\left(\mathrm{GO}_{\mathrm{Rt}}\right)$ & $\begin{array}{l}\text { Most inferior, posterior, outward point on the } \\
\text { Rt. mandibular angle }\end{array}$ \\
\hline Gonion $_{L t}\left(\mathrm{Go}_{\mathrm{Lt}}\right)$ & $\begin{array}{l}\text { Most inferior, posterior, outward point on the Lt. } \\
\text { mandibular angle }\end{array}$ \\
\hline Menton (Me) & Most inferior point on the symphysis outline \\
\hline Condylion $_{\mathrm{Rt}}\left(\mathrm{Cd}_{\mathrm{Rt}}\right)$ & $\begin{array}{l}\text { Most superior point on the head of the Rt. } \\
\text { mandibular condyle }\end{array}$ \\
\hline Condylion $_{\mathrm{Lt}}\left(\mathrm{Cd}_{\mathrm{Lt}}\right)$ & $\begin{array}{l}\text { Most superior point on the head of the Lt. } \\
\text { mandibular condyle }\end{array}$ \\
\hline Nasion (Na) & $\begin{array}{l}\text { The most anterior point of the nasofrontal } \\
\text { suture on the midsagittal plane }\end{array}$ \\
\hline Bagion (Ba) & $\begin{array}{l}\text { The midpoint of the anterior border of the } \\
\text { foramen magnum }\end{array}$ \\
\hline \multicolumn{2}{|l|}{ Plane } \\
\hline HRP & Horizontal reference plane: $\mathrm{PO}_{\mathrm{Rt}}-\mathrm{OrRt}$ - $\mathrm{PO}_{\mathrm{Lt}}$ \\
\hline SRP & $\begin{array}{l}\text { Sagittal reference plane: perpendicular to HRP } \\
\text { including } \mathrm{Na}-\mathrm{Ba} \text { line }\end{array}$ \\
\hline $\mathrm{CP}$ & $\begin{array}{l}\text { Coronal plane: perpendicular to HRP and SRP, } \\
\text { measurement plane }\end{array}$ \\
\hline
\end{tabular}




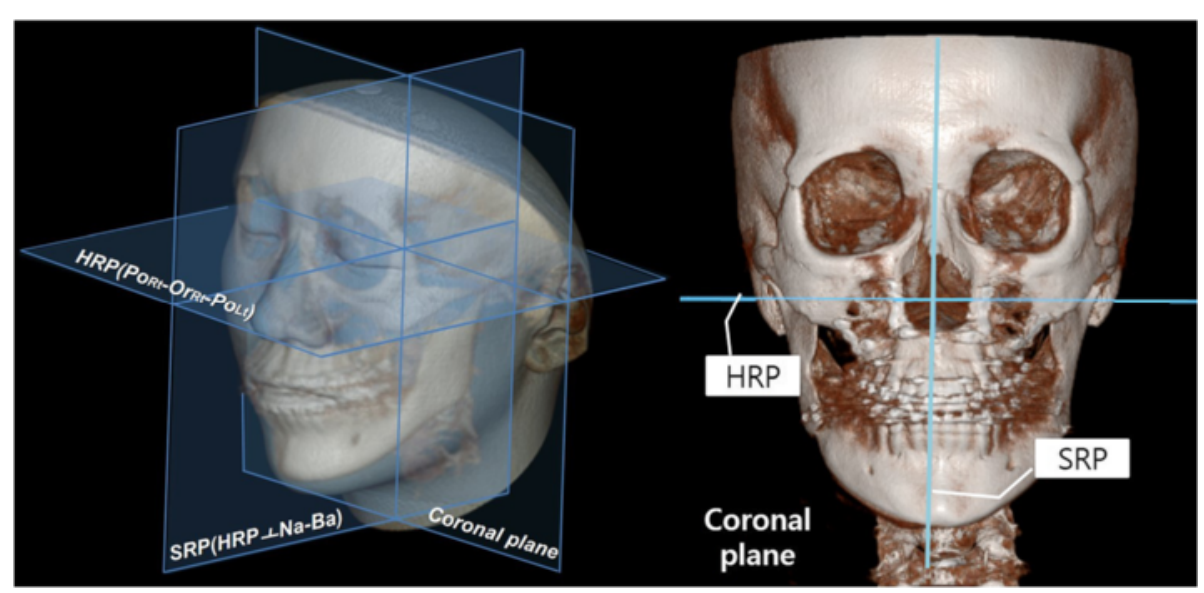

Fig. 1 Horizontal reference plane (HRP) is $\mathrm{Po}_{\mathrm{Rt}}-\mathrm{Or}_{\mathrm{Rt}}-\mathrm{PO}_{\mathrm{Lt}}$, sagittal reference plane(SRP) is the plane perpendicular to horizontal reference plane including $\mathrm{Na}$-Ba line, coronal plane is the plane perpendicular to horizontal and sagittal reference plane

group. However, angle of $\mathrm{Go}_{\mathrm{Rt}}-\mathrm{Me}^{\prime}-\mathrm{Go}_{\mathrm{Lt}}(\mathrm{A}), \mathrm{Cd}$ '-Go'-Me' (C), distance from $\mathrm{Me}$ ' to line $\mathrm{Cd}_{\mathrm{Rt}}{ }^{-} \mathrm{Cd}_{\mathrm{Lt}}(\mathrm{H})$, ratio of length $\mathrm{Me}$-Go' to length $\mathrm{Me}^{\prime}-\mathrm{Go}_{\mathrm{Rt}} \mathrm{Go}_{\mathrm{Lt}}$ (I/F ratio) were statistically significant between men and women (Table 6).

Angle of $\mathrm{Go}_{\mathrm{Rt}}{ }^{-} \mathrm{Me}^{\prime}-\mathrm{Go}_{\mathrm{Lt}}^{\prime}(\mathrm{A})$, distance from line $\mathrm{Go}_{\mathrm{Rt}} \mathrm{Go}_{\mathrm{Lt}}$ to line $\mathrm{Cd}_{\mathrm{Rt}} \mathrm{Cd}_{\mathrm{Lt}}(\mathrm{G})$, distance from $\mathrm{Me}^{\prime}$ to line $\left.\mathrm{Cd}_{\mathrm{Rt}}{ }^{-} \mathrm{Cd}_{\mathrm{Lt}} \mathrm{H}\right)$, ratio of distance from $\mathrm{Me}^{\prime}$ to line $\mathrm{Cd}_{\mathrm{Rt}}{ }^{-} \mathrm{Cd}_{\mathrm{Lt}}$ to distance from $\mathrm{Me}$ ' to line $\mathrm{Go}_{\mathrm{Rt}} \mathrm{Go}_{\mathrm{Lt}}(\mathrm{H} / \mathrm{F}$ ratio), ratio of length of line $\mathrm{Me}^{\prime}-\mathrm{Go}^{\prime}$ to distance from $\mathrm{Me}^{\prime}$ to line $\mathrm{Go}_{\mathrm{Rt}}{ }_{\mathrm{Go}} \mathrm{Lot}_{\mathrm{Lt}}$ (I/F ratio), ratio of length of line $\mathrm{Go}_{\mathrm{Rt}}{ }^{-} \mathrm{Go}_{\mathrm{Lt}}$ to distance from $\mathrm{Me}$ ' to line $\mathrm{Go}_{\mathrm{Rt}} \mathrm{Go}_{\mathrm{Lt}}(\mathrm{D} / \mathrm{F}$ ratio) had a statistically significant difference between experimental group and control A group in women group. Average angular measurement of $\mathrm{Cd}-\mathrm{Go}-\mathrm{Me}$ was $138.49 \pm 1.57$ in the experimental group and $118.90 \pm$ 1.60 in control B group, but there was no statistically significant difference. The ratio of distance from $\mathrm{Go}_{\mathrm{Rt}} \mathrm{Go}_{\mathrm{Lt}}$ to line $\mathrm{Cd}_{\mathrm{Rt}} \mathrm{Cd}_{\mathrm{Lt}}$ to distance from line $\mathrm{Me}^{\prime}$ to line $\mathrm{Go}_{\mathrm{Rt}}{ }^{-G o^{\prime}}{ }_{\mathrm{Lt}}$ (G/F ratio), ratio of distance from $\mathrm{Me}^{\prime}$ to line $\mathrm{Cd}_{\mathrm{Rt}} \mathrm{Cd}_{\mathrm{Lt}}$ to distance from $\mathrm{Me}^{\prime}$ to line $\mathrm{Go}_{\mathrm{Rt}}{ }^{-} \mathrm{Go}_{\mathrm{Lt}}$ (H/F) ratio) showed a statistically significant difference between experimental group and control B group (Table 7).

Angle of $\mathrm{Go}^{\prime}{ }_{\mathrm{Rt}}-\mathrm{Me}^{\prime}-\mathrm{Go}_{\mathrm{Lt}}$ (A), distance from line $\mathrm{Go}_{\mathrm{Rt}} \mathrm{Go}_{\mathrm{Lt}}$ to line $\mathrm{Cd}_{\mathrm{Rt}} \mathrm{Cd}_{\mathrm{Lt}}(\mathrm{G})$, distance from $\mathrm{Me}^{\prime}$ to line $\mathrm{Cd}_{\mathrm{Rt}}{ }^{-} \mathrm{Cd}_{\mathrm{Lt}}(\mathrm{H})$, ratio of distance from $\mathrm{Go}_{\mathrm{Rt}} \mathrm{Go}_{\mathrm{Lt}}$ to line $\mathrm{Cd}_{\mathrm{Rt}} \mathrm{Cd}_{\mathrm{Lt}}$ to distance from line $\mathrm{Me}^{\prime}$ to line $\mathrm{Go}_{\mathrm{Rt}} \mathrm{Goo}_{\mathrm{Lt}}$ (G/F ratio), ratio of distance from Me' to line $\mathrm{Cd}_{\mathrm{Rt}} \mathrm{Cd}_{\mathrm{Lt}}$ to distance from $\mathrm{Me}$ to line $\mathrm{Go}_{\mathrm{Rt}}{ }^{-} \mathrm{Go}_{\mathrm{Lt}}(\mathrm{H} / \mathrm{F}$ ratio), ratio of distance from $\mathrm{Me}$ ' to Go' to distance from line $\mathrm{Me}^{\prime}$ to line $\mathrm{Go}_{\mathrm{Rt}}{ }^{-} \mathrm{Go}_{\mathrm{Lt}}^{\prime}$ (I/F ratio), ratio of distance from $\mathrm{Go}_{\mathrm{Rt}}^{\prime}$ to $\mathrm{Go}_{\mathrm{Lt}}^{\prime}$ to distance from $\mathrm{Me}$ ' to line $\mathrm{Go}_{\mathrm{Rt}}{ }^{-}-\mathrm{Go}_{\mathrm{Lt}}(\mathrm{D} / \mathrm{F})$ ratio showed a statistically significant difference between experimental group and control A group in men. And, distance from line $\mathrm{Go}_{\mathrm{Rt}} \mathrm{Go}_{\mathrm{Lt}}^{\prime}$ to line $\mathrm{Cd}_{\mathrm{Rt}} \mathrm{Cd}_{\mathrm{Lt}}(\mathrm{G})$, distance from $\mathrm{Me}^{\prime}$ to line $\mathrm{Cd}_{\mathrm{Rt}}{ }^{-} \mathrm{Cd}_{\mathrm{Lt}}(\mathrm{H})$, ratio of distance from $\mathrm{Go}_{\mathrm{Rt}}^{\prime} \mathrm{Go}_{\mathrm{Lt}}^{\prime}$ to line $\mathrm{Cd}_{\mathrm{Rt}} \mathrm{Cd}_{\mathrm{Lt}}$ to distance from line $\mathrm{Me}^{\prime}$ to line $\mathrm{Go}_{\mathrm{Rt}} \mathrm{Goo}_{\mathrm{Lt}}$ (G/F ratio), ratio of distance from $\mathrm{Me}$ ' to line $\mathrm{Cd}_{\mathrm{Rt}}{ }^{-} \mathrm{Cd}_{\mathrm{Lt}}$ to distance from $\mathrm{Me}^{\prime}$

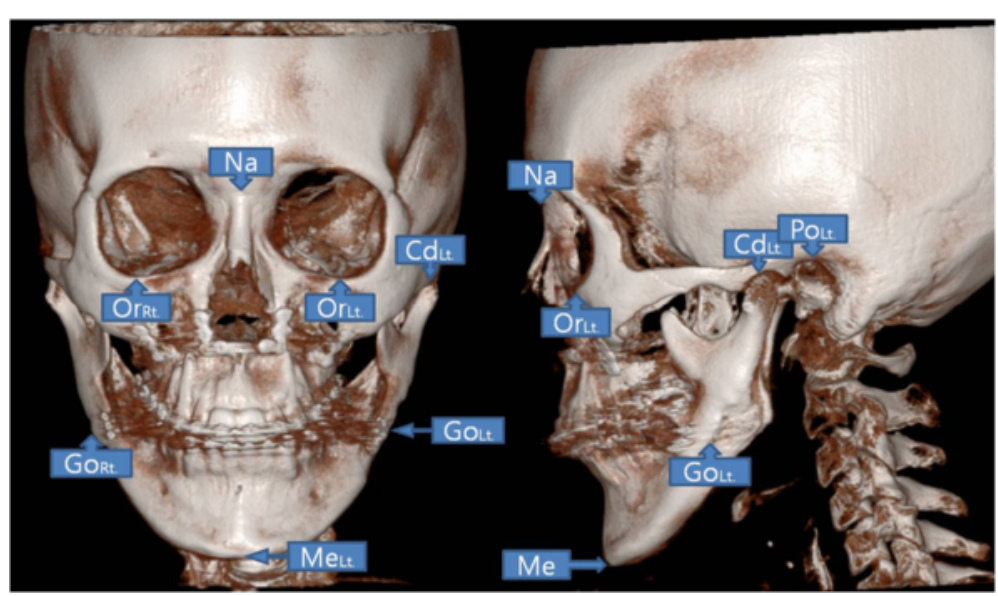

Fig. 2 Reference points on three-dimensional image 


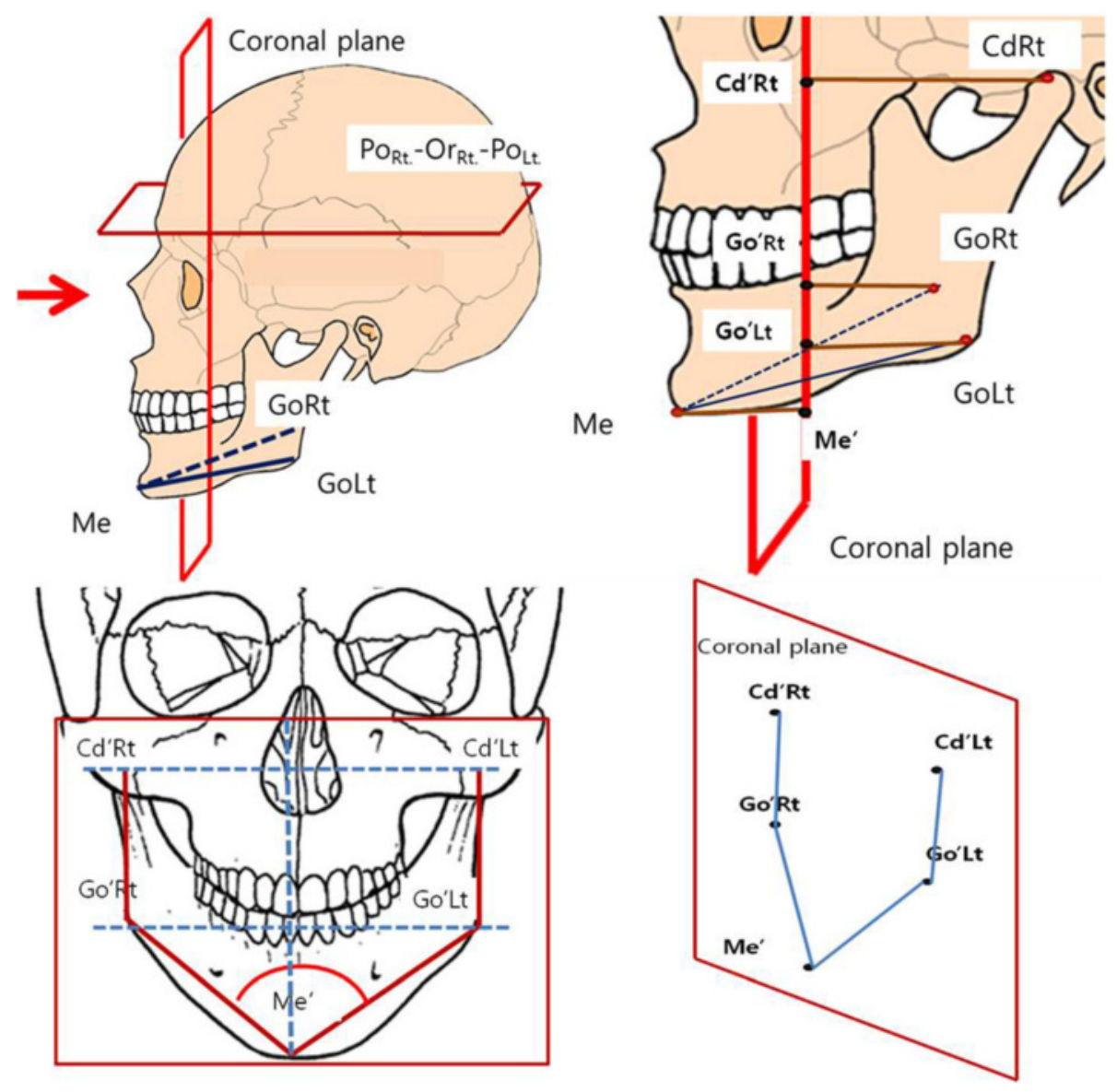

Fig. 3 Measurement concepts of linear and angular measurement. All measurements are investigated with second points on coronal plane (measurement plane). Second reference point is the meeting point of coronal plane and perpendicular line from anatomical reference point to coronal plane. (ex. if anatomical reference point is $\mathrm{Cd}_{\mathrm{Rt}}$, second reference point is $C \mathrm{~d}_{\mathrm{Rt}}^{\prime}$ )

to line $\mathrm{Go}_{\mathrm{Rt}} \mathrm{Go}_{\mathrm{Lt}}(\mathrm{H} / \mathrm{F}$ ratio) statistically significant difference between experimental group and control B group in men (Table 8).

\section{Discussion}

The current operational plan for the conventional orthognathic surgery is based on analysis of lateral cephalometry to determine the moving amount and posteroanterior (PA) cephalometry to investigate maxillary canting and asymmetry of chin [9]. Occlusal plane angle and incisal inclination based on analysis of lateral cephalometry is an important measurement in the plan for rotational orthognathic surgery with maxillary posterior impaction [10]. And common rotational surgery is focused on anteroposterior movement and aesthetic improvement of lateral profile. However, most patients want not only proper maxillary anteroposterior position, but also aesthetic, slender, symmetric mandibular inferior border line in frontal view, so called V-line. However, the surgical plan for orthognathic surgery based on PA cephalometry to accomplish optimal postoperative frontal profile has a limited application in practical operation, with no guarantee of an aesthetic frontal face $[11,12]$. Skeletal investigation based on 2D modality like PA cephalometry tracing is a limited adaptation for surgical planning because of the difficulty in positioning the reoriented natural head position and selecting specific anatomical points in overlay of structure. So, there is no referential measurement for surgical planning of the frontal profile. As a result, most surgeons have done lateral mandibular angle reduction, mandibular body contouring based on their experience and preference. There is no standard measurement.

Many clinicians have suggested several different methods to convert two-dimensional radiograph to threedimensional image for solving the problem of 2D-based surgical plan [13-16]. But, former methods had several limitations to apply in practical operational procedure because of the radiographic magnification distortion, and the need to measure a reference point repeatedly on various image views. So, the establishment of plan for orthognathic surgery still depends on lateral cephalometry, and 
Table 5 Linear measurement and angular measurement (Figs. 3, 4)

\begin{tabular}{|c|c|}
\hline & Description \\
\hline $\mathrm{GO}_{\mathrm{Rt}}^{\prime}-\mathrm{Me}^{\prime}-\mathrm{GO}_{\mathrm{Lt}}^{\prime}$ & Angle of $\mathrm{GO}_{\mathrm{Rt}}-\mathrm{Me}-\mathrm{GO}_{\mathrm{Lt}}$ fitted on coronal plane (A) \\
\hline $\mathrm{Cd}_{\mathrm{Rt}}^{\prime}-\mathrm{Me}^{\prime}-\mathrm{Cd}_{\mathrm{Lt}}^{\prime}$ & Angle of $C d_{R t}-M e-C d_{L t}$ fitted on coronal plane (B) \\
\hline $\mathrm{Cd}^{\prime}-\mathrm{Go}^{\prime}-\mathrm{Me}^{\prime}$ & Angle of Cd-Go-Me fitted on coronal plane (C) \\
\hline $\mathrm{GO}_{\mathrm{Rt}}^{\prime}-\mathrm{GO}_{\mathrm{Lt}}^{\prime}$ & Length of $\mathrm{Go}_{\mathrm{Rt}}-\mathrm{Go}_{\mathrm{Lt}}$ fitted on coronal plane (D) \\
\hline $\mathrm{Cd}_{\mathrm{Rt}}^{\prime} \mathrm{Cd}_{\mathrm{Lt}}^{\prime}$ & Length of $\mathrm{Go}_{\mathrm{Rt}}-\mathrm{Go}_{\mathrm{Lt}}$ fitted on coronal plane (E) \\
\hline$M e^{\prime}-G_{R t}^{\prime}{ }_{R t} \mathrm{Go}_{L t}^{\prime}$ & $\begin{array}{l}\text { Distance from Me to } \mathrm{Go}_{\mathrm{Rt}}-\mathrm{Go}_{\mathrm{Lt}} \text { line fitted on } \\
\text { coronal plane }(\mathrm{F})\end{array}$ \\
\hline $\mathrm{Go}_{\mathrm{Rt}}^{\prime} \mathrm{Go}_{\mathrm{Lt}}^{\prime} \mathrm{Cd}_{\mathrm{Rt}}^{\prime} \mathrm{Cd}_{\mathrm{Lt}}^{\prime}$ & $\begin{array}{l}\text { Distance from } \mathrm{Go}_{\mathrm{Rt}} \text { to } \mathrm{Go}_{\mathrm{Lt}} \text { line to } \mathrm{Cd}_{\mathrm{Rt}}-\mathrm{Cd}_{\mathrm{Lt}} \text { line } \\
\text { fitted on coronal plane }(\mathrm{G})\end{array}$ \\
\hline$M e^{\prime}-\mathrm{Cd}_{{ }_{\mathrm{Rt}}} \mathrm{Cd}_{\mathrm{Lt}}^{\prime}$ & $\begin{array}{l}\text { Distance from Me to } C d_{R t}-C d_{L t} \text { line fitted on } \\
\text { coronal plane }(H)\end{array}$ \\
\hline$M e^{\prime}-G o^{\prime}$ & Length of Me-Go fitted on coronal plane (I) \\
\hline Me'Go'-body & $\begin{array}{l}\text { Distance from Me-Go line to the height of } \\
\text { contour of mandibular body fitted on the } \\
\text { coronal plane }(J)\end{array}$ \\
\hline G/F ratio & Ratio of $\mathrm{Go}_{\mathrm{Rt}}^{\prime} \mathrm{Go}_{\mathrm{Lt}}^{\prime}{ }^{-} \mathrm{Cd}_{\mathrm{Rt}}^{\prime} \mathrm{Cd}_{\mathrm{Lt}}^{\prime}$ to $\mathrm{Me}^{\prime}-\mathrm{Go}_{\mathrm{Rt}}^{\prime} \mathrm{Go}_{\mathrm{Lt}}^{\prime}(\mathrm{K})$ \\
\hline $\mathrm{H} / \mathrm{F}$ ratio & Ratio of $\mathrm{Me}^{\prime}-\mathrm{Cd}_{\mathrm{Rt}}^{\prime} \mathrm{Cd}_{\mathrm{Lt}}^{\prime}$ to $\mathrm{Me}^{\prime}-\mathrm{Go}_{\mathrm{Rt}}^{\prime} \mathrm{Go}_{\mathrm{Lt}}^{\prime}(\mathrm{L})$ \\
\hline I/F ratio & Ratio of $\mathrm{Me}^{\prime}-\mathrm{Go}^{\prime}$ to $\mathrm{Me}^{\prime}-\mathrm{Go}_{\mathrm{Rt}}^{\prime} \mathrm{Go}_{\mathrm{Lt}}^{\prime}(\mathrm{M})$ \\
\hline D/F ratio & Ratio of $\mathrm{Go}_{\mathrm{Rt}}^{\prime}-\mathrm{Go}_{\mathrm{Lt}}^{\prime}$ to $\mathrm{Me}^{\prime}-\mathrm{Go}_{\mathrm{Rt}}^{\prime} \mathrm{GO}_{\mathrm{Lt}}^{\prime}(\mathrm{N})$ \\
\hline $\mathrm{J} / \mathrm{I}$ ratio & Ratio of Me'Go'-body to Me'-Go' (O) \\
\hline
\end{tabular}

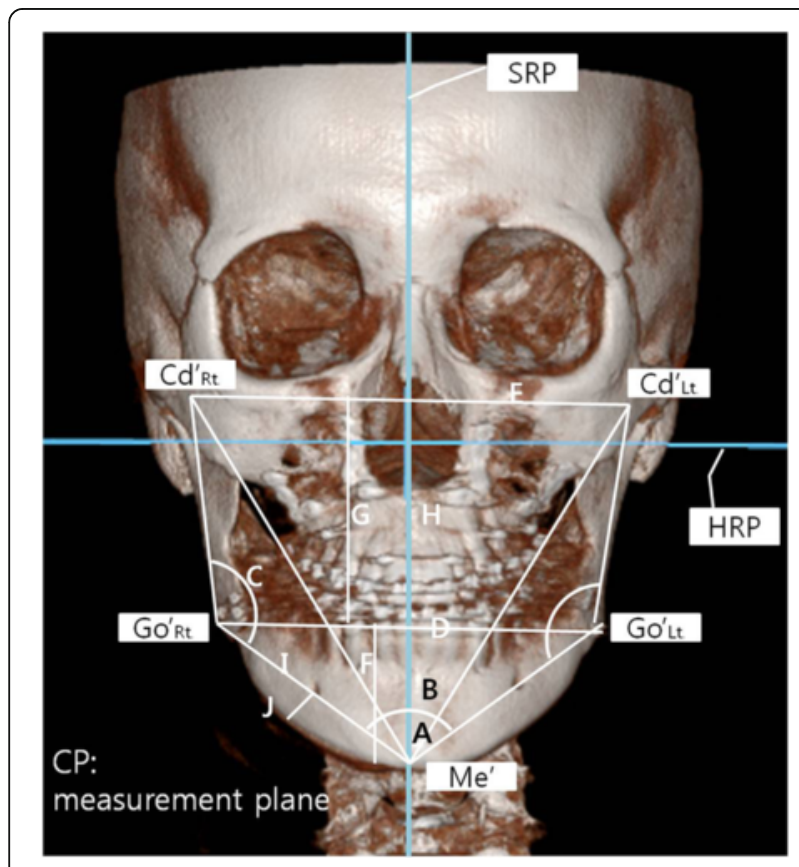

Fig. 4 Linear measurement $(\mathrm{mm})$ is $\mathrm{GO}_{\mathrm{Rt}}^{\prime}-\mathrm{Go}_{L t}^{\prime}$ line, $\mathrm{Cd}_{\mathrm{Rt}}^{\prime}-\mathrm{Cd}_{L \mathrm{t}}^{\prime}$ line,

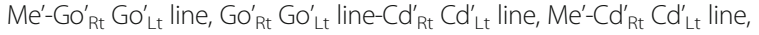
Me'-Go' line, Me'Go'line-mandibular outer surface of body, and angular measurement ( $\left.{ }^{\circ}\right)$ is angle of $\mathrm{Go}_{\mathrm{Rt}}^{\prime} \mathrm{Me}^{\prime} \mathrm{Go}_{\mathrm{Lt}}^{\prime} \mathrm{Cd}^{\prime} \mathrm{Go}^{\prime} \mathrm{Me}^{\prime}, \mathrm{Cd}^{\prime} \mathrm{Go}^{\prime} \mathrm{Me}^{\prime}$
Table 6 Mean and standard deviation of linear and angular measurement on mandibular outer surface of male group and female group in the experimental group

\begin{tabular}{|c|c|c|c|c|c|}
\hline & \multicolumn{2}{|c|}{ Female $(n=47)$} & \multicolumn{2}{|c|}{ Male $(n=38)$} & \multirow[t]{2}{*}{$p$ value } \\
\hline & Mean & SD & Mean & SD & \\
\hline A & 100.74 & 2.14 & 105.37 & 3.62 & $0.001^{* * *}$ \\
\hline B & 65.04 & 2.62 & 64.97 & 2.94 & 0.38 \\
\hline$C(R t)$ & 138.49 & 1.57 & 134.52 & 2.57 & $0^{* * *}$ \\
\hline$C(L t)$ & 139.04 & 1.57 & 135.05 & 2.69 & $0^{* * *}$ \\
\hline D & 92.57 & 3.81 & 38.5 & 3.94 & 0.81 \\
\hline E & 109.64 & 5.45 & 115.47 & 5.15 & 0.6 \\
\hline $\mathrm{F}$ & 36.17 & 2.89 & 36.05 & 3.84 & 0.08 \\
\hline G & 49.43 & 3.45 & 53.21 & 4.04 & 0.29 \\
\hline $\mathrm{H}$ & 85.60 & 4.03 & 89.26 & 5.64 & $0.04^{*}$ \\
\hline I(Rt) & 56.43 & 4.07 & 58.87 & 3.84 & 0.94 \\
\hline$J(\mathrm{Rt})$ & 7.87 & 1.23 & 8.34 & 1.32 & 0.50 \\
\hline I(Lt) & 56.40 & 3.98 & 58.92 & 3.82 & 0.94 \\
\hline$J(L t)$ & 7.85 & 1.23 & 8.32 & 1.30 & 0.72 \\
\hline $\mathrm{G} / \mathrm{F}$ & 1.38 & 0.16 & 1.49 & 0.21 & 0.14 \\
\hline $\mathrm{H} / \mathrm{F}$ & 2.38 & 0.16 & 2.49 & 0.21 & 0.14 \\
\hline I/F & 1.56 & 0.07 & 1.64 & 0.13 & $0.02^{*}$ \\
\hline $\mathrm{D} / \mathrm{F}$ & 2.57 & 0.15 & 2.76 & 0.26 & 0.11 \\
\hline $1 / J$ & 7.31 & 1.09 & 7.18 & 0.95 & 0.42 \\
\hline
\end{tabular}

${ }^{*} p<0.05,{ }^{* * *} p<0.001$. A angle of $\mathrm{Go}^{\prime}{ }_{\mathrm{Rt}} \mathrm{Me}^{\prime} \mathrm{Go}_{\mathrm{Lt}}^{\prime}\left({ }^{\circ}\right), B$ angle of $\mathrm{Cd}^{\prime} \mathrm{Go}^{\prime} \mathrm{Me}^{\prime}\left({ }^{\circ}\right), \mathrm{C}$ angle of $\mathrm{Cd}^{\prime} \mathrm{Go}^{\prime} \mathrm{Me}^{\prime}\left({ }^{\circ}\right), D$ length of $\mathrm{Go}_{\mathrm{Kt}}^{\prime}-\mathrm{Go}_{\mathrm{Lt}}^{\prime}$ line $(\mathrm{mm})$,

$E$ length of $\mathrm{Cd}_{\mathrm{Rt}}{ }^{-} \mathrm{Cd}_{\mathrm{Lt}}$ line $(\mathrm{mm}), F$ distance from $\mathrm{Me}^{\prime}$ to $\mathrm{Go}^{\prime}{ }_{\mathrm{Rt}} \mathrm{Go}_{\mathrm{Lt}}{ }_{\mathrm{t}}$ line $(\mathrm{mm})$, $G$ distance from $\mathrm{Go}_{\mathrm{Rt}} \mathrm{Go}_{\mathrm{Lt}}^{\prime}$ line to $\mathrm{Cd}^{\prime}{ }_{\mathrm{Rt}} \mathrm{Cd}_{\mathrm{Lt}}^{\prime}$ line $(\mathrm{mm}), \mathrm{H}$ distance from $\mathrm{Me}^{\prime}-\mathrm{Cd}_{\mathrm{Rt}} \mathrm{Cd}_{\mathrm{Lt}}^{\prime}$ line $(\mathrm{mm})$, I length of $\mathrm{Me}^{\prime}-\mathrm{Go}^{\prime}$ line $(\mathrm{mm}), J$ distance from Me'Go' line-mandible outer surface of body $(\mathrm{mm})$

there is no practical and predictable planning method for investigating frontal view. As a result, many practitioners decide to operate with one's own preference or feel. Consequently, revisional surgery may be performed to correct an unsatisfactory postoperative outcome.

With the development of 3D computerized tomography, 3D reconstruction modality and analyzing software program, the use of 3D analysis method for getting more aesthetic surgical result is studied by many clinicians. So, in this research, we try to study a useful and valuable reference measurement required for establishing three dimensional treatment planning by using $3 \mathrm{D}$ image of the patient. There are several problems that must be solved prior to establishment of 3D treatment planning. First, it has to reproduce natural head position (NHP) of the patient. Second, an accurate image of the hard tissue and soft body and tooth must be obtained from the low radiation dose. Third, all processes have to be handled in one advanced software [17]. However, 3D analysis based on NHP as a reference plane is still controversial because of its sensitive reproducibility technologically and it is difficult to standardize [18]. So, in this 
Table 7 Mean and standard deviation of linear and angular measurement on mandibular outer surface of female in the experimental group, control A group, control B group, and significant test

\begin{tabular}{|c|c|c|c|c|c|c|c|c|}
\hline & \multicolumn{2}{|c|}{ Experimental group } & \multicolumn{3}{|c|}{ Control A } & \multicolumn{3}{|c|}{ Control B } \\
\hline & Mean & SD & Mean & SD & $p$ & Mean & SD & $p$ \\
\hline A & 100.74 & 2.14 & 133.50 & 6.06 & $0^{* * *}$ & 100.50 & 3.14 & 0.14 \\
\hline B & 65.04 & 2.62 & 64.60 & 2.91 & 0.56 & 62.80 & 2.53 & 0.88 \\
\hline$C(R t)$ & 138.49 & 1.57 & 118.90 & 1.60 & 0.91 & 138.40 & 1.35 & 0.83 \\
\hline$C(L t)$ & 139.04 & 1.57 & 119.60 & 2.01 & 0.17 & 138.50 & 1.58 & 0.35 \\
\hline D & 92.57 & 3.81 & 95.00 & 5.08 & 0.53 & 92.90 & 4.72 & 0.58 \\
\hline$E$ & 109.64 & 5.45 & 109.00 & 4.64 & 0.33 & 109.40 & 3.72 & 0.15 \\
\hline$F$ & 36.17 & 2.89 & 18.80 & 3.01 & 0.68 & 36.20 & 4.08 & 0.12 \\
\hline G & 49.43 & 3.45 & 67.60 & 6.70 & $0.01^{* *}$ & 85.60 & 4.03 & 0.49 \\
\hline H & 85.60 & 4.03 & 86.40 & 7.68 & $0.01^{* *}$ & 87.50 & 4.12 & 0.94 \\
\hline I(Rt) & 56.43 & 4.07 & 51.10 & 3.87 & 0.88 & 1.44 & 0.24 & 0.91 \\
\hline$J(R t)$ & 7.87 & 1.23 & 7.70 & 1.42 & 0.88 & 2.44 & 0.24 & 0.69 \\
\hline I(Lt) & 56.40 & 3.98 & 51.10 & 3.87 & 0.62 & 1.58 & 0.11 & 0.97 \\
\hline$J(L t)$ & 7.85 & 1.23 & 7.70 & 1.42 & 0.92 & 2.59 & 0.21 & 0.58 \\
\hline $\mathrm{G} / \mathrm{F}$ & 1.38 & 0.16 & 3.69 & 0.75 & 0.68 & 56.90 & 4.36 & $0.03^{*}$ \\
\hline $\mathrm{H} / \mathrm{F}$ & 2.38 & 0.16 & 4.69 & 0.75 & $0^{* * *}$ & 8.50 & 1.27 & $0.03^{*}$ \\
\hline $1 / F$ & 1.56 & 0.07 & 2.77 & 0.35 & $0^{* * *}$ & 56.90 & 4.36 & 0.10 \\
\hline $\mathrm{D} / \mathrm{F}$ & 2.57 & 0.15 & 5.15 & 0.69 & $0^{* * *}$ & 8.50 & 1.27 & 0.74 \\
\hline I/J & 7.31 & 1.09 & 6.79 & 1.09 & 0.66 & 6.80 & 0.88 & 0.58 \\
\hline $\begin{array}{l}E \text { lengt } \\
G \text { dista } \\
M e^{\prime}-C d\end{array}$ & $05,{ }^{* *} p<0$ & $p<0$ & $A$ ang & of $C$ & ${ }_{\mathrm{Rt}} \mathrm{Me}^{\prime}$ & 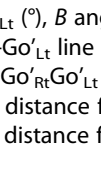 & $\begin{array}{l}\text { gle of } \\
(\mathrm{mm}) \text {, }\end{array}$ & \\
\hline
\end{tabular}

study, the standard plane is horizontal reference plane(HRP) accomplished by both the porion side and right side orbitale and sagittal reference plane(SRP) perpendicular to $\mathrm{FH}$ plane passing through basion. CT image of patient was reorganized into $3 \mathrm{D}$ reconstructive image and reoriented according to HRP and SRP, and coronal plane perpendicular to HRP and SRP is the practical measurement plane.

In this study, we did not select the anatomical reference point directly on 3D reconstructed image. Instead, we coordinated multiplanar reformatted reference plane that is horizontal, sagittal, and coronal plane to set up the reference point. This has the advantage of simplicity and ease in comparison to setting up a reference point on complicated $\mathrm{X}, \mathrm{Y}$, and Z-axes converted from a 3D reconstructed image.

There were several locations to consider. First, it was the gonion location. There was a trouble of deciding the accurate gonion location of patient performing mandibular angle reduction. However, we resolved this isue by setting the most inferolateral point of the proximal
Table 8 Mean and standard deviations of linear and angular measurement on mandibular outer surface of male in the experimental group, control A group, control B group, and significant test

\begin{tabular}{|c|c|c|c|c|c|c|c|c|}
\hline & \multicolumn{2}{|c|}{ Experimental group } & \multicolumn{3}{|c|}{ Control A } & \multicolumn{3}{|c|}{ Control B } \\
\hline & Mean & SD & Mean & SD & $p$ & Mean & SD & $p$ \\
\hline A & 105.37 & 3.62 & 132.30 & 9.87 & $0.01^{* *}$ & 105.30 & 4.85 & 0.25 \\
\hline B & 64.97 & 2.94 & 61.90 & 5.45 & 0.35 & 63.70 & 2.50 & 0.35 \\
\hline$C(R t)$ & 134.52 & 2.57 & 117.80 & 3.88 & 0.13 & 134.90 & 2.08 & 0.27 \\
\hline$C(L t)$ & 135.05 & 2.69 & 118.10 & 3.75 & 0.47 & 135.10 & 2.28 & 0.33 \\
\hline D & 38.5 & 3.94 & 99.50 & 4.25 & 0.53 & 99.30 & 3.53 & 0.58 \\
\hline$E$ & 115.47 & 5.15 & 113.80 & 5.73 & 0.62 & 115.60 & 4.88 & 0.69 \\
\hline 1 & 36.05 & 3.84 & 20.30 & 4.42 & 0.84 & 35.50 & 3.78 & 0.99 \\
\hline G & 53.21 & 4.04 & 72.80 & 7.33 & $0^{* * *}$ & 61.10 & 13.14 & $0.03^{*}$ \\
\hline $\mathrm{H}$ & 89.26 & 5.64 & 93.10 & 8.35 & 0.12 & 96.60 & 13.09 & $0.03^{*}$ \\
\hline I(Rt) & 58.87 & 3.84 & 52.80 & 3.77 & 0.65 & 59.50 & 4.50 & 0.40 \\
\hline$J(\mathrm{Rt})$ & 8.34 & 1.32 & 7.90 & 1.60 & 0.69 & 8.50 & 1.18 & 0.75 \\
\hline I(Lt) & 58.92 & 3.82 & 52.80 & 3.77 & 0.69 & 59.60 & 4.50 & 0.45 \\
\hline$J(L t)$ & 8.32 & 1.30 & 7.90 & 1.60 & 0.67 & 8.50 & 1.18 & 0.84 \\
\hline $\mathrm{G} / \mathrm{F}$ & 1.49 & 0.21 & 3.85 & 1.47 & $0^{* * *}$ & 1.75 & 0.45 & $0.03^{*}$ \\
\hline $\mathrm{H} / \mathrm{F}$ & 2.49 & 0.21 & 4.85 & 1.47 & $0^{* * *}$ & 2.75 & 0.45 & $0.03^{*}$ \\
\hline I/F & 1.64 & 0.13 & 2.75 & 0.80 & $0^{* * *}$ & 1.69 & 0.13 & 0.48 \\
\hline $\mathrm{D} / \mathrm{F}$ & 2.76 & 0.26 & 5.21 & 1.58 & $0^{* * *}$ & 2.82 & 0.29 & 0.99 \\
\hline I/J & 7.18 & 0.95 & 7.00 & 1.84 & 0.21 & 7.08 & 0.77 & 0.69 \\
\hline
\end{tabular}

${ }^{*} p<0.05,{ }^{* *} p<0.01,{ }^{* * *} p<0.001$. A angle of $\mathrm{Go}_{\mathrm{Rt}}{ }_{\mathrm{t}} \mathrm{Me}^{\prime} \mathrm{Go}_{\mathrm{Lt}}\left({ }^{\circ}\right), B$ angle of $\mathrm{Cd}^{\prime} \mathrm{Go}^{\prime} \mathrm{Me}^{\prime}\left({ }^{\circ}\right), C$ angle of $\mathrm{Cd}^{\prime} \mathrm{Go}^{\prime} \mathrm{Me}^{\prime}\left({ }^{\circ}\right)$, $D$ length of $\mathrm{Go}^{\prime}{ }_{\mathrm{Rt}}-\mathrm{Go}_{\mathrm{Lt}}^{\prime}$ line $(\mathrm{mm})$, $E$ length of $\mathrm{Cd}_{\mathrm{Rt}}^{\prime} \mathrm{Cd}_{\mathrm{Lt}}$ line $(\mathrm{mm}), F$ distance from $\mathrm{Me}^{\prime}$ to $\mathrm{Go}_{\mathrm{Rt}} \mathrm{Go}_{\mathrm{Lt}}^{\prime}$ line $(\mathrm{mm})$, $G$ distance from $\mathrm{Go}^{\prime}{ }_{\mathrm{Rt}} \mathrm{Go}^{\prime}{ }_{\mathrm{Lt}}$ line to $\mathrm{Cd}_{\mathrm{Rt}} \mathrm{Cd}^{\prime}{ }_{\mathrm{Lt}}$ line $(\mathrm{mm}), H$ distance from $\mathrm{Me}^{\prime}-\mathrm{Cd}_{\mathrm{Rt}} \mathrm{Cd}_{\mathrm{Lt}} \mathrm{L}$ line $(\mathrm{mm}), I$ length of $\mathrm{Me}^{\prime}-\mathrm{Go}^{\prime}$ line $(\mathrm{mm}), J$ distance from $\mathrm{Me}^{\prime} \mathrm{Go}^{\prime}$ line-mandibular outer surface of body $(\mathrm{mm})$

segment to gonion. Second, there was a trouble deciding on HRP, including porion and orbitale. Setting up HRP with three points among porions and orbitale of both sides is difficult in asymmetric patients, but we found the nasion and basion to set up SRP, and we set up HRP to the plane perpendicular to SRP which contains three points or passed near four points. Third, the head of condyle (condylon) was located inside zygomatic arch. However, by using 3 type mutiplanar reformatted image, condylon could be easily selected.

In a comparative study of the experimental group, control A, B group, statistically significant measured value in aesthetic mandibular outline was angular measurement of $\mathrm{Go}_{\mathrm{Rt}} \mathrm{Me}^{-}-\mathrm{Go}_{\mathrm{Lt}}$, and linear measurement of ratio of $\mathrm{Me}^{\prime}-\mathrm{Go}^{\prime}$ to $\mathrm{Me}^{\prime}-\mathrm{Go}_{\mathrm{Rt}} \mathrm{Go}_{\mathrm{Lt}}$, ratio of $\mathrm{Go}_{\mathrm{Rt}}{ }^{-}-\mathrm{Go}_{\mathrm{Lt}}$ to $\mathrm{Me}-\mathrm{Go}_{\mathrm{Rt}} \mathrm{Go}_{\mathrm{Lt}}$.

Angular measurement of $\mathrm{Go}_{\mathrm{Rt}}{ }^{-} \mathrm{Me} \mathrm{e}^{-}-\mathrm{Go}_{\mathrm{Lt}}$ in experimental group was shown to have a statistically significant difference with value in control A group, but, not with control B group. Mean value of $\mathrm{Go}_{\mathrm{Rt}}{ }^{-}-\mathrm{Me}^{\prime}-\mathrm{Go}_{\mathrm{Lt}}{ }_{\mathrm{t}}$ angle of women is $100.74 \pm 2.14$, that of men is $105.37 \pm 3.62$ linear 
measurement. Mean value of Cd'-Go'-Me' angle is not statistically significant between experimental group and control A group, but there is an apparent difference. So, it may be a useful measurement $\left(134^{\circ}\right.$ and $117^{\circ}$ in men group, $138^{\circ}$, and $118^{\circ}$ in women). Ratio of $\mathrm{Go}_{\mathrm{Rt}} \mathrm{Go}_{\mathrm{Lt}}{ }^{\prime} \mathrm{Cd}^{\prime}{ }_{\mathrm{Rt}} \mathrm{Cd}_{\mathrm{Lt}}^{\prime}$ to $\mathrm{Me}^{\prime}-\mathrm{Go}_{\mathrm{Rt}} \mathrm{Go}_{\mathrm{Lt}}$, ratio of $\mathrm{Me}^{\prime}-\mathrm{Cd}_{\mathrm{Rt}} \mathrm{Cd}_{\mathrm{Lt}}$ to $\mathrm{Me}^{\prime}-\mathrm{Go}_{\mathrm{Rt}} \mathrm{Go}_{\mathrm{Lt}}$ in experimental group had a statistically significant difference with both control A, B group, and it may be the influence of varying position of gonion due to mandibular angle reduction.

The measured value obtained from this study will not become the absolute standard value to evaluate for aesthetic mandibular outline. However, because there are no research that suggest the linear and angular measurement value to analyze for 3D image, measurement of this study will be a valuable measurement to the application of operational plan establishment and intraoperative guidance. Moreover, if long-term study is conducted with a larger population, measuring point and measured values will be standardized as the reference value for $3 \mathrm{D}$ morphometric investigation of frontal profile and surgical planning for more satisfying aesthetic appearance. Pitch, roll, and yaw which is difficult to evaluate in 2D radiograph will be easy. Particularly, the volume difference and midline discrepancy of the mandible in an asymmetric patient could be evaluated. And it could be calculated by the quantitative amount of bone reduction and movement for more satisfying frontal profile. Afterwards, it is regarded to provide the reference value which can easily apply clinically and be helpful to the establishment of the diagnosis of orthognathic surgery or treatment planning to achieve a more aesthetic mandibular outline and frontal appearance.

The limitation of this study is that we did not evaluate soft tissue appearance of patient group, but we investigated bony structure. It is difficult to evaluate soft tissue appearance by analyzing bony structure because of personal difference of adaptation of the soft body, lip thickness, adipose tissue and amount of muscle growth, and texture. Soft tissue and bony structure must be studied separately $[19,20]$. According to the development of 3D image technology and modality, the soft body can be reconstructed precisely, and the active research including the reaction of the soft body according to the hard tissue change, soft tissue prediction according to operation, overlay of the soft tissue and the hard tissue are being studied. So, this study will be upgraded to investigate soft and bony tissues.

\section{Conclusion}

In Results described above, the difference was in the measured value between men and women. However, angle of $\mathrm{Go}_{\mathrm{Rt}}-\mathrm{Me}-\mathrm{Go}_{\mathrm{Lt}}$ fitted on coronal plane, ratio of $\mathrm{Me}^{\prime}-\mathrm{Cd}_{\mathrm{Rt}}{ }^{\mathrm{Cd}} \mathrm{Lt}_{\mathrm{Lt}}$ to $\mathrm{Me}^{\prime}-\mathrm{Go}_{\mathrm{Rt}} \mathrm{Go}_{\mathrm{Lt}}$, ratio of $\mathrm{Me}$ '-Go' to
$\mathrm{Me}^{\prime}-\mathrm{Go}_{\mathrm{Rt}} \mathrm{Go}_{\mathrm{Lt}}$, ratio of $\mathrm{Go}_{\mathrm{Rt}}-\mathrm{Go}_{\mathrm{Lt}}$ to $\mathrm{Me}^{\prime}-\mathrm{Go}_{\mathrm{Rt}} \mathrm{Go}_{\mathrm{Lt}}$ are observed with statistically significant differences. So, this measurement could be helpful in making a surgical plan for a more aesthetic frontal profile, especially aesthetic mandibular inferior outline in frontal view.

\section{Acknowledgments}

All authors have viewed and agreed to the submission.

This work was supported by a 2-year research grant of Pusan National University, Korea.

\section{Authors' contributions}

Dr. STL designed this study and carried out all processes with other authors. Dr. NRC, Dr. JMS participated in data collection. Dr. SHS made contributions to the interpretation of data and revision of manuscript. All authors read and approved the final manuscript.

\section{Competing interests}

The authors declare that they have no competing interests.

\section{Consent for publication}

Not applicable.

\section{Ethics approval and consent to participate}

Not applicable.

Received: 1 October 2016 Accepted: 8 November 2016

Published online: 25 November 2016

\section{References}

1. Enacar A, Taner T, Manav O (2001) Effects of single- or double-jaw surgery on vertical dimension in skeletal Class III patients. Int J Adult Orthodon Orthognath Surg 16:30-35

2. Reyneke JP, Evans WG (1990) Surgical manipulation of the occlusal plane. Int J Adult Orthodon Orthognath Surg 5:99-110

3. Wolford LM, Chemello PD, Hilliard F (1994) Occlusal plane alteration in orthognathic surgery-part I: effects on function and esthetics. Am J Orthod Dentofacial Orthop 106:304-316

4. Proffit WR, Fields HW Jr, Ackerman JL (2000) Contemporary orthodontics, 3rd edn. Mosby, St Louis

5. Athanasiou AE (1995) Orthodontic Cephaolmetry St Louis, Mosby-Wolfe

6. Ishiguro K, Krogman WM, Mazaheri M, Harding RL (1976) A longitudinal study of morphological craniofacial patterns via P-A x-ray headfilms in cleft patients from birth to six years of age. Cleft Palate J 13:104-126

7. Xia JJ, Gateno J, Teichgraeber JF (2009) New clinical protocol to evaluate craniomaxillofacial deformity and plan surgical correction. J Oral Maxillofac Surg 67:2093-2106

8. Lee WD, Yoo CK, Choi JY (2010) Quantitative assessment of nasal and upper lip changes after Le Fort I osteotomy surgery using a 3-dimensional computed tomography. J Korean Assoc Maxillofac Plast Reconst Surg 32(s1):13-14

9. Yoon HJ, Rebellato J, Keller EE (2005) Stability of the Le Fort I osteotomy with anterior internal fixation alone: a case series. J Oral Maxillofac Surg 63:629-634

10. Kwon KY, Lee SH, Kwon DG (1999) Clinical articles : three dimensional analysis of maxillofacial structure by frontal and lateral cephalogram. J Korean Assoc Maxillofac Plast Reconst Surg 21:174-188

11. Ghafari J, Cater PE, Shofer FS (1995) Effect of film-object distance on posteroanterior cephalometric measurements: suggestions for standardized cephalometric methods. Am J Orthod Dentofacial Orthop 108:30-37

12. Yoon YJ, Kim DH, Yu PS, Kim HJ, Choi EH, Kim KW (2002) Effect of head rotation on posteroanterior cephalometric radiographs. Angle Orthod 72:36-42

13. Grayson B, Cutting C, Bookstein FL, Kim H, McCarthy JG (1988) The three-dimensional cephalogram: theory, technique, and clinical application. Am J Orthod Dentofacial Orthop 94:327-337

14. Grayson BH, McCarthy JG, Bookstein F (1983) Analysis of craniofacial asymmetry by multiplane cephalometry. Am J Orthod 8:217-224 
15. Quevedo LA, Ruiz JV, Quevedo CA (2011) Using a clinical protocol for orthognathic surgery and assessing a 3-dimensional virtual approach: current therapy. J Oral Maxillofac Surg 69:623-637

16. Orentlicher G, Goldsmith D, Horowitz A (2010) Applications of 3-dimensional virtual computerized tomography technology in oral and maxillofacial surgery: current therapy. J Oral Maxillofac Surg 68:1933-1959

17. Gateno J, Xia JJ, Teichgraeber JF (2011) New 3-dimensional cephalometric analysis for orthognathic surgery. J Oral Maxillofac Surg 69:606-622

18. Ellis E, McNamara J (1983) Cephalometric reference planes-sella nasion vs frankfort horizontal. Int J Adult Orthodon Orthognath Surg 3:81-87

19. Sforza C, Peretta R, Grandi G, Ferronato G, Ferrario VF (2008) Soft tissue facial planes and masticatory muscle function in skeletal class III patients before and after orthognathic surgery treatment. J Oral MAxillofac Surg 66:691-698

20. Almeida RC, Cevidanes LHS, Carvalho FAR, Motta AT, Almeida MAO, Styner M et al (2011) Soft tissue response to mandibular advancement using 3D CBCT scanning. Int J Oral Maxillofac Surg 40:353-359

21. Wolford LM, Hilliard FW, Dugan DJ (1985) Surgical Treatment Objective-a systematic approach to the prediction tracing. The C. V. Mosby Company

22. Kim KH, Choy KC et al (2001) Cephalometric norms of the hard tissues of korean for orthognathic surgery. J Korean Assoc Oral Maxillofac Surg 27:221-230

\section{Submit your manuscript to a SpringerOpen ${ }^{\circ}$ journal and benefit from:}

- Convenient online submission

- Rigorous peer review

- Immediate publication on acceptance

- Open access: articles freely available online

- High visibility within the field

- Retaining the copyright to your article

Submit your next manuscript at $>$ springeropen.com 